\title{
Topics in Applied Macrodynamic Theory
}

Peter Flaschel, Gangolf Groh, Christian Proaño i Willi Semmler, Heidelberg i Berlin: Springer-Verlag, 2008, 512 str.

Osnovna tematika kojom se autori knjige Topics in Applied Macrodynamic Theory bave je primjena teoretskih modela makroekonomske dinamike u empirijskim istraživanjima. Čitanje knjige zahtijeva poznavanje osnovnih pojmova ne samo iz područja ekonomije (makroekonomske teorije i njezinih različitih pristupa, s posebnim naglaskom na odnose između makroekonomskih varijabli tijekom vremena), već i iz područja matematike, ekonometrije, dinamičke analize, linearne algebre, pa i teorije kaosa. Stoga čitalačku publiku treba tražiti ili među znanstvenicima i istraživačima ili među polaznicima doktorskih studija iz područja ekonomije.

Iako se u svom pristupu autori najviše oslanjaju na kejnezijansku tradiciju, kao osnovni pristup modeliranju koriste u literaturi najrašireniji okvir dinamičkih stohastičkih modela opće ravnoteže. To implicira da se u odabiru analiziranih modela autori uglavnom koncentriraju na one u kojima se pretpostavlja kako ekonomski agenti optimiziraju između dva vremenska razdoblja, ali modeli istodobno sadrže pretpostavke kao što su monopolistička konkurencija, «ljepljive» cijene (sticky prices) kao i nominalne i/ili realne rigidnosti. Poglavlja knjige se uglavnom temelje na već prethodno objavljenim radovima njenih autora, ali i odabranim radovima drugih autora. Međutim, ovdje se ne radi o pukoj reprodukciji članaka jer se rezultati izneseni u prethodno objavljenim člancima propituju u kontekstu drugih modela odabranih za prikaz u knjizi. Time što sadrži prikupljena prethodna istraživanja različitih autora, knjiga čitatelju omogućuje 
dobivanje uvida u različitosti modeliranja pojedinih problema. Čitatelja se izuzetno vješto upućuje na druge reference, pa knjiga djeluje poticajno za daljnje istraživanje. Primjerice, u svakom slučaju u kojem rezultati prikazanih modela odstupaju od uobičajenih ${ }^{1}$, autori detaljno upozoravaju koje pretpostavke dovode do tih različitosti, istovremeno upućujući čitatelja i na originalne izvore u literaturi kako bi i sami mogli izvesti zaključke.

Kod dinamičkih modela, prema mišljenju autora, najznačajniji su povratni mehanizmi koji utječu na druge varijable u modelu. Unatoč tome što su i u teorijskoj i u empirijskoj literaturi intenzivno istraživani pojedini segmenti povratnih mehanizama proizašlih iz makroekonomskih promjena i njihovih utjecaja na tržište proizvoda, tržište rada i tržišta kapitala, oni nisu sustavno ugrađivani u modele. Autori upravo u toj činjenici vide osnovni doprinos ove knjige. Naime, čimbenici kao što su nelinearne povratne veze, heterogenost ekonomskih subjekata te različite informacijske i strukturne nesavršenosti dovode do potrebe da se ekonomski sustav ne izučava samo u jednom, već u nekoliko makroekonomskih okvira kako bi se pokušalo razjasniti zašto na nekim tržištima, primjerice tržištu rada, ne pronalazimo ni modelski ni empirijski ravnotežno stanje, a niti stabilnu putanju prema ravnotežnom stanju.

Nakon predgovora, u prvom je poglavlju pod nazivom «Period Models, Continuous Time and Applied Macrodynamics» naglasak stavljen na potrebu razlikovanja diskretnih gospodarskih promjena i empirijske analize utemeljene na kontinuiranim vremenskim serijama. To djelomice proizlazi iz činjenice da postoji razlika između frekvencije pravog procesa generiranja podataka i procesa prikupljanja podataka za potrebe makroekonomskog modeliranja. Kod diskretnih je vremenskih modela nužno razmotriti učestalost opažanja. Ako je razdoblje između opažanja dovoljno kratko, tada rezultati diskretnih i kontinuiranih vremenskih modela, što detaljno na primjerima pokazuju autori, ne moraju odstupati. Međutim, brojni su slučajevi u kojima postoje odstupanja i u modelima, pa onda i u njihovim rezultatima i zaključcima koji se mogu iz takvih rezultata izvesti. To uvodno poglavlje služi za naglašavanje potrebe formuliranja dinamičkih

${ }^{1}$ U engleskoj literaturi često nazivanih mainstream. 
odnosa među makroekonomskim varijablama, a istodobno razgraničava i neke važne pojmove o kojima se govori u nastavku knjige.

Knjigu autori zatim dijele u dva dijela. U prvom dijelu, koji se proteže od drugog do petog poglavlja, razmatraju modeliranje zatvorenog gospodarstva. Drugi dio, koji se sastoji od pet poglavlja, proširuje analizu i na otvorena gospodarstva. Nakon svakog poglavlja dolazi kratki zaključak i popis literature, a tamo gdje autori zaključuju da je neophodna, nalazi se i detalina matematička razrada modela analiziranih u prethodnom poglavlju. $\mathrm{Na}$ kraju knjige postoji i matematički dodatak s razradom nekoliko korisnih teorema za analiziranje dinamičkih sustava.

Drugo poglavlje, «The AS-AD Framework: Origins, Problems and Progress», započinje proširenjem tradicionalnog AS-AD modela neoklasične sinteze. Autori pokazuju kako taj, u udžbenicima često zastupljen model, dovodi do nekonzistentne realne/nominalne dihotomije ${ }^{2}$ ako se pretpostavi kratkovidno savršeno predviđanje ekonomskih agenata ${ }^{3}$. Autori zatim razmatraju neokejnezijanski pristup, s postupnim prilagodbama plaća i cijena. Zatim se formulira i detaljno analizira novi («zreli») kejnezijanski model u kojem se pretpostavlja da i rad i kapital mogu biti ili previše ili premalo iskorišteni, te da se i cijene i plaće samo postupno prilagođavaju toj neravnoteži.

Treće poglavlje, «Wage-Price Dynamics: Basic Structural Form, Estimation and Analysis», započinje s tradicionalnom analizom spirale plaća i cijena u kojoj se koriste različite mjere pritiska potražnje i troškova na tržištu rada i tržištu proizvoda, te razlikuju kratkotrajne i trajne promjene u troškovnim pritiscima. Autori pokazuju kako je i u tradicionalnom modelu moguće pronaći važne makroekonomske povratne mehanizme, iako se u literaturi izuzetno rijetko istražuju njihovi učinci na makroekonomsku stabilnost. Primjer takvog povratnog mehanizma se pojavljuje kada rastuća inflacija dovodi do pada realnih kamatnih stopa koje zatim stimuliraju potražnju

\footnotetext{
${ }^{2}$ Naime, model može rezultirati eksplozivnom nominalnom dinamikom koja se može tehnikom «skokovite varijable» svesti na putanju prema ravnotežnom stanju.

${ }^{3}$ Pojam myopic perfect foresight se u ekonomskim modelima odnosi na pretpostavku prema kojoj ekonomski subjekti imaju relativno malu grešku predviđanja u kratkom roku.
} 
za investicijama i trajnim potrošačkim dobrima. To dovodi do daljnjeg povećanja ekonomske aktivnosti, što dodatno potiče rast cijena. Istraživanja ovakvih veza postoje u literaturi, ali se one vrlo rijetko modeliraju u okviru makroekonomskih modela.

U četvrtom se poglavlju naslovljenom «Estimation and Analysis of an Extended AD-AS Model» testira prethodno razmatrani teoretski model (u nekoliko varijanti) na podacima za SAD. Posebno se analiziraju dinamička svojstva modela, uz različite pretpostavke s ciljem pronalaženja stabilnih rješenja sustava. Rezultati uglavnom upućuju na zaključak da premala fleksibilnost plaća i prevelika fleksibilnost cijena dovode do nestabilne dinamike sustava.

Peto poglavlje, «Linking Goods with Labor Markets: Okun's Law and Beyond», započinje s metodološkim osnovama za empirijsku ocjenu vremenski promjenjivih koeficijenata, a zatim slijedi empirijska analiza na primjeru SAD-a. Uloga četvrtog i petog poglavlja nije svedena samo na ilustraciju teoretskih postavki, već se na temelju dobivenih rezultata empirijskih ocjena u daljnjim poglavljima modificiraju pretpostavke prethodno prikazanih teoretskih modela.

U drugom se dijelu knjige model proširuje otvaranjem gospodarstva. U šestom poglavlju, pod naslovom «Exchange Rate and Stock Market Dynamics in a Two-Country Model», analiza započinje Dornbuschovim modelom dinamike tečaja, a zatim se analizira i poznati dinamički Blanchardov model. Integriranjem ta dva modela za dvije zemlje, javlja se problem koji se uobičajenim tehnikama škole racionalnih očekivanja ne može modelirati na jednostavan način, što autorima daje motiv za razradu novog modela.

Sedmo poglavlje, «Macroeconomic Imbalances and Inflation Dynamics in a Mundell-Fleming-Tobin Framework», započinje standardnim modelom za malo otvoreno gospodarstvo, koji sadrži kejnezijanska ograničenja potražnje na tržištu roba kao i nesavršenu supstituciju financijskih sredstava (umjesto nepokrivenog pariteta kamatnih stopa). Glavni cilj poglavlja je 
razdvajanje fundamentalno destabilizirajućih faktora u dvije jednadžbe akumulacije u modelu koje se tiču unutarnjih i vanjskih deficita (suficita) - u jednadžbi sektora države i jednadžbi tekućeg računa bilance plaćanja. Autori pronalaze veliki broj primjera kompleksne strukture povratnih mehanizama: Hicksov učinak raspoloživog dohotka, Pigouov učinak razine cijena, Keynesov učinak razine cijena, Mundell-Tobinov učinak inflacijskih očekivanja u funkciji potrošnje i funkciji investicija, Dornbuschov učinak tečaja, portfolio učinke i interakciju varijabli stanja i varijabli tijeka. To omogućava pojavu raznih (ne)stabilnih rješenja. Prema mišljenju samih autora, takav je pristup relativno bogat raznim implikacijama, ali nedovoljan za davanje nedvosmislenih odgovora onima koji preferiraju jednostavne zaključke koji će u sljedećoj iteraciji rezultirati jednostavnim preporukama za donošenje mjera ekonomske politike.

Osmo poglavlje, «Currency Crises, Credit Rationing and Monetary Policy in Emerging Markets», smješta analizu valutnih kriza u makroekonomski kontekst postupnih prilagodbi cijena i plaća, te pokazuje kako promjene ne samo nominalnog, nego i realnog tečaja utječu na makroekonomska kretanja u srednjem roku. Model je empirijski testiran na primjeru meksičke valutne i financijske krize (1994.-95.) te kriza u nekim istočno-azijskim zemljama. Model upućuje da nagla deprecijacija nominalnog tečaja srednjoročno može imati različite učinke ovisno o elastičnosti ukupnih investicija na kamatnu stopu. U kratkom pak roku, neke odluke ekonomske politike mogu biti uspiešne ili neuspiešne, što ovisi o makroekonomskim karakteristikama samih zemalja u kojima se primjenjuju.

Deveto poglavlje, «Keynesian Dynamics and International Linkages in a Two-Country Model», sadrži prikaz novih makroekonomskih modela otvorenog gospodarstva koji se, slično dinamičkim stohastičkim modelima opće ravnoteže za zatvoreno gospodarstvo, temelje na pretpostavci racionalnih očekivanja. U poglavlju se analizira teoretski model dvije zemlje koji se temelji na neravnotežnom pristupu u kojem su dva velika otvorena gospodarstva međusobno povezana putem trgovine, cijena i financijskih kanala. 
Deseto poglavlje, «Outlook: Supply Constraints in Demand-Driven Macromodels», prikazuje kejnezijanske modele novčanog rasta u okviru kojih se posebno razmatra problem promjene režima (regime-switching), te time upućuje na one segmente modela koje je potrebno dodatno razraditi.

Posebna se vrijednost knjige sastoji u tome da autori neprestano pokazuju kako postoji veza između ekonomske teorije, ekonomskog modeliranja i empirijskih istraživanja. Često su pretpostavke koje se ugrađuju u modele potkrijepljene konkretnim referencama na prethodno provedena empirijska istraživanja. S različitih se aspekata tako analiziraju poznati ekonomski učinci kao što su Mundellov učinak ili Taylorovo pravilo, koji u okviru modela analiziranih u ovoj knjizi ne daju uvijek očekivane rezultate.

Knjiga sadrži detaljan komparativni pregled različitih dinamičkih i statičkih makroekonomskih modela, koji se javljaju u brojnim udžbenicima makroekonomije i služe kao podloga za brojna empirijska istraživanja. Tim prikazom autori zorno pokazuju kako, iako je literatura u ovom području izuzetno bogata, postoji još mnogo neodgovorenih pitanja u dinamičkim odnosima pojedinih ključnih makroekonomskih varijabli. Međutim, isto tako pokazuju kako odabirom određenog modela usvajamo i niz pretpostavki na kojima on počiva, a koje u empirijskim istraživanjima konkretnih gospodarstava nisu uvijek potvrđene. Time autori upućuju na razmišljanje o kompleksnim vezama između pojedinih ekonomskih fenomena, koje se za potrebe donošenja ekonomsko-političkih odluka često pojednostavljuje i ispod temeljne udžbeničke razine.

Valerija Botrić Ekonomski institut, Zagreb 